\title{
Article
}

\section{The Limits of Green Finance: A Survey of Literature in the Context of Green Bonds and Green Loans}

\author{
David Gilchrist ${ }^{1}{ }^{\circledR}$, Jing $\mathrm{Yu}^{2}$ and Rui Zhong ${ }^{1, *}$ \\ 1 UWA Business School, The University of Western Australia, Perth, WA 6009, Australia; \\ david.gilchrist@uwa.edu.au \\ 2 Business School, The University of Sydney, Sydney, NSW 2006, Australia; jing.yu@sydney.edu.au \\ * Correspondence: rui.zhong@uwa.edu.au; Tel.: +61-864-883-867
}

Citation: Gilchrist, D.; Yu, J.; Zhong,

R. The Limits of Green Finance:

A Survey of Literature in the Context of Green Bonds and Green Loans.

Sustainability 2021, 13, 478. https:// doi.org/10.3390/su13020478

Received: 8 December 2020

Accepted: 4 January 2021

Published: 6 January 2021

Publisher's Note: MDPI stays neutral with regard to jurisdictional clai$\mathrm{ms}$ in published maps and institutional affiliations.

Copyright: $\odot 2021$ by the authors. Licensee MDPI, Basel, Switzerland. This article is an open access article distributed under the terms and conditions of the Creative Commons Attribution (CC BY) license (https:// creativecommons.org/licenses/by/ $4.0 /)$.

\begin{abstract}
In response to the rapid development of green finance, this study evaluates a systematic literature survey with a focus on the determinants and the potential benefits of corporate engagement in environmentally responsible practices in the context of green bonds and green loans. We show that research has discovered that environmentally responsible practices not only enhance shareholder value but also the value accrued to nonfinancial stakeholders. Further, we provide an updated overview of research developments in relation to green bonds and syndicated loans. Lastly, we discuss the limitations in the nascent green finance research and propose new lines of research supporting our aim of advancing our knowledge of sustainable investments.
\end{abstract}

Keywords: green finance; green bonds; syndicated loans; sustainable investments

\section{Introduction}

The acceptance of global warming as a critical policy area across governments has heightened the demand for solutions to maintaining economic growth while assuring the ecological sustainability of our planet into the future [1,2]. Wang and Zhi [3] describe the green finance market as "a credit intermediary of environmental protection's capital" (pg 313) reflecting hope that the market mechanism will allocate funds toward more socially acceptable drivers of economic growth via social investment. However, the discussion is based around the need for balance between ecological outcomes and economic growth with the pendulum swinging from one to the other as circumstances (such as the Global Financial Crisis) dictate [4]. Indeed, driven by ever-increasing concerns surrounding global environmental sustainability and commerce's need to retain their social licence, sustainable investing has grown exponentially attracting USD 12 trillion in 2018 alone (Global Sustainable Investment Alliance, 2018).

However, the speed of expansion in this sector has not been without difficulties. For instance, questions arise relating to identifying the principal objective function of companies-what should they focus on and how should they balance profitability with broader sustainability questions relevant to the whole community-and, economy-wide, the need to balance the trade-off between economic growth and social priorities such as environmental protection. The structures of social investment, and the opinions surrounding their development and operation, are also varied and complex with a substantial and growing literature focused on various aspects of the asset class, including whether or not the capitalist finance system is the best to start when considering ecological sustainability [5]. Therefore, we need to focus our study and so we seek to respond to the urgency surrounding the need to understand the economic and financial implications of corporate greenness and corporate social responsibility in the context of green bonds and green loans and from a corporate perspective only as we cannot do justice to a study examining the entire field in one paper. 
As such, we are motivated by the need to identify key questions and opportunities to investigate the phenomenon of green finance with a view to encouraging further research in this critical area and to inform our own research program moving forward. Indeed, the need for building a greater understanding of green financing mechanisms that might better support the capacity of green finance to steer investment in a more ecologically balance direction has been identified for some time [3]. If solutions can be identified that reduce the complexity and encourage the eventual development of a green economy, the future of ecological sustainability is much closer to reality.

We undertake this study by stepping back and taking stock of the learnings identified so far-both in terms of problem identification and problem rectification-in these two areas. To do this, we undertook a systematic literature survey with a focus on scholarly responses to the important questions of what drives companies to engage in environmentally responsible practices, what are the potential benefits of corporate greenness, what are the recent developments, and what are some of the major unresolved challenges warranting further research? We discuss these findings in the context of green bonds and green loans. The literature survey process included a Boolean search using various typological nomenclature such as "green finance", "green bonds", "green loans", "social licence to operate" and "green regulation". This process yielded published articles that were then examined for relevance to this work. As such, papers that either provided rich context and/or specific discussion pertaining to green loans, green bonds and the firm's social licence to operate where incorporated into our discourse.

Despite the exponential growth in both the desire for, and the implementation of, sustainable investments, academic research has identified more questions than answers regarding the reframing of the corporate purpose which not only emphasises shareholder values but also the values of other nonfinancial stakeholders. By reviewing the literature, we observe evidence pointing toward managerial opportunism where managers tend to exploit corporate environmental commitments for their own private benefit such as social networking, enhancing job prospects and achieving financial incentives. However, it should also be noted that abundant evidence demonstrates value creation arising from sound corporate environmental performance. This stream of literature highlights two salient benefits arising out of corporate environmental engagement: (1) insurance against future environmental disasters; (2) and social trust built with local communities including customers, suppliers and governments.

There are a number of mechanisms that companies can deploy to achieve a green reputation and which will attract investors seeking green investments. As described above, our study particularly focuses on two emerging markets-green bonds and green loans. However, both of these markets are still in their infancy. For instance, although the first green bond was issued in 2007 by the European Investment Bank, this market has only gained traction over the last 5 years. Notwithstanding the newness of the instruments, and while at first glance confining our scope to green bonds and green loans may seem overly restrictive, these instruments are seen as central to influencing increased responsiveness of companies to ecological sustainability. Indeed, these instruments are often viewed by central banks as a promising means of achieving a green economy via greening the financial system itself. Hence, interest and implementation soared in recent years with a push by central banks as external political pressures, including the signing of the Paris Agreement, increased dramatically. Given the dearth of academic work in the areas of green bonds and loans, we provide an updated overview of scholarly developments in these two markets and call for future research to investigate the economic consequences of these two emerging green finance instruments.

The remainder of this paper is organised as follows: Section 2 reviews an extensive stream of literature on corporate environmental performance in broad terms, followed by Section 3 which analyses recent developments in green bond and green loans market research. Section 4 provides remarks on our conclusion identifying limitations in the two 
nascent green finance areas. This section also proposes lines of new research aimed at advancing the knowledge of these new investment areas and concludes the paper.

\section{Literature Review-Green Bonds and Green Loans}

Material and rapidly changing climate conditions in recent years have increased the popularly felt urgency for developing enforceable policies around the world to hold global warming to below 2 degrees Celsius. One of the most important ways to achieve this goal is to create a green economy by building a green financial system. While the political and economic practicalities of building a green financial system that supports a reduction in carbon emissions in the real economy remain unresolved, this green policy focus has driven a surge in two different but interconnected green debt market instruments in the last decade-green bonds and green loans. Our literature survey of this emerging topic begins with inquiries into the theoretical reasoning that underlies the nascent growth of green debt markets, followed by an examination of the literature focused on the efficacy of a green financial system. Under the renewed corporate objective function, where broader non-financial constituencies are of growing importance, we sift through the existing studies examining the spill over effects of corporate environmental performance and the green financial system on stakeholders including shareholders, debtholders, customers and suppliers more broadly.

\subsection{What Motivates a Company to Be Green}

Corporate purpose is a hotly debated topic in economics and finance research. The shareholder view, famously ascribed to Milton Friedman, holds that the sole purpose of corporations is to make profits [6]. The stakeholder view, on the other hand, stresses the importance of all stakeholders in the company's decision-making process. According to Jensen [7], stakeholders refer to "individuals and groups who can substantially affect, or can be affected by the welfare of the firm". This broad definition covers not only financial claimholders but also employees, customers, suppliers, communities and government officials. This definition also suggests that the welfare of the firm needs to be dependent on its meeting the broader expectations of the community, in this case, in relation to the "greenness" of its activities. In contrast to the longstanding roots of shareholder value maximisation in economics, the theoretical underpinning of the broader stakeholder view is rather contentious despite its recognised societal benefits.

As is widely known, Jensen and Meckling's [8] seminal paper regards a firm as a nexus of contracts focusing on shareholder primacy as central to corporate purpose. This "traditional" perspective is warranted because equity investors are the owners of the firm and bear significant costs at liquidation as residual claimants on firm value. However, this perspective has also become more complex due to changes in attitudes of the shareholders themselves, as well as those of other stakeholders, leading to changes in expectations of management and driving different managerial behaviours. For instance, Benabou and Tirole [9] demonstrate that corporate social responsibility itself has resulted from managers pursuing their self-interest while Masulis and Reza [10] reinforce this perspective by empirically showing that shareholders reduce their valuations of firm cash holdings as corporate donations increase while managers actually advance their personal interests by making donations to director-affiliated charities. As insider ownership increased following the 2003 Dividend Tax Cut in the United States, Cheng et al. [11] find that firms with moderate insider ownership cut corporate social responsibility (CSR) investments by more than firms with low levels of insider ownership.

Instead of focusing on an agency outcome resulting from CSR, other studies directly examine the shareholder effects of CSR. Indeed, Fernando et al. [12] document that institutional investors shun firms that increase their environmental friendliness. Based on short-term event study approaches, Krueger [13] reaches a similar conclusion reporting a weak but negative stock market reaction toward positive corporate environmental, social and governance (ESG) events. Chang et al. [14] focus on negative CSR incidents for a 
sample of international companies from 47 countries. While they find that overall market reactions are negative over both the short- and long-term horizons, ex-ante firm-level CSR investments cannot mitigate the adverse market reactions resulting from negative ESG events-breaking the promise of value-creating CSR spending.

Narrowing the focus from a broad ESG vision to corporate environmental issues we see more scepticism. Karpoff et al. [15] put it succinctly: corporate environmental violations do not impose a long-term reputational impact on the firm because such breaches do not directly affect the firm's contractual relationships. They consistently show that stock market value declines at the announcement of environmental-based litigation are almost of the same magnitude as the legal penalties incurred as a result of those same environmental violations. This implies that firms that violated the US environmental regulations did not suffer from any reputational losses. Further, Wang et al. [16,17] document a trivial regulatory fine of USD 15,000 among large-cap publicly listed companies that breached environmental lawsuits in China. The lack of repercussions over corporate environmental misconduct in the financial market and the over-emphasised importance of corporate environment engagements stir up much academic debate over the efficacy of environmental commitments.

There may be no surprise then that Cao et al. [18] criticise the socially responsible institutional investors who place heavy emphasis on ESG issues but overlook quantitative signals of value. In keeping with this conjecture, they find that a composite of 11 mispricing signals could reliably predict the returns of stocks held by socially responsible professional investors. This finding is consistent with a market over-emphasis on ESG-related issues identified by Cui and Docherty [19] who performed an event study by assessing the stock market reactions to corporate negative ESG incidents in the US from 2010 to 2018, showing evidence of short-term market reaction over the ESG news but a price reversal over the long-term. Therefore, there is a sense that the rhetoric of greenness in corporate activity is disconnected from the financial outcomes achieved.

\subsection{Real Benefits to Being Green}

Despite the evidence pointing toward the ambiguous impacts on shareholders of corporate greenness, the rise of public awareness in corporate environmental responsibility as well as the implicit and explicit ramifications of corporate environmental wrongdoing is undoubted. This, in turn, is reflected in investment decision making. For example, the period from 2014 to 2018 saw the total value of responsible investment assets in the United States grow at an annualised rate of $16 \%$ to reach USD 12 trillion by 2018 or $14 \%$ of the world GDP. It is difficult to attribute all the sustainable investments made by savvy investors to an agency-motivated corporate action. In this section, we delve into the literature and seek to understand the important benefits of corporate environmental investments.

In total, two salient benefits emerge from the extant literature justifying corporate investments made in eco-friendly projects: (1) an insurance-like hedging strategy as a precautionary tool for corporate environmental risk; and (2) a reputation-building strategy to accumulate valuable social capital. By way of example, on 20 April 2010, the Deepwater Horizon oil rig leased to BP PLC exploded roughly 40 miles off the coast of Louisiana in the Gulf of Mexico. To 2013, BP has paid approximately USD 13 billion to individuals, businesses and the government settling more than 100,000 spill-related claims. The remarkable legal penalties had grave implications not only for BP but also the oil and gas industry as a whole, while they acted as a warning to industry more broadly. Heflin and Wallace [20] observe a systematic stock price decline for same-industry oil companies operating in US waters in the aftermath of the BP oil spill. Recently, more systematic research conducted by Shapiro and Walker [21] documents a $60 \%$ decline in carbon emissions from US manufacturing despite a substantive increase in manufacturing outputs. Intriguingly, they show that implicit regulation tax arising from regulatory shifts account for most of the air pollution cuts, dominating other factors such as changes in productivity and trade arrangements. 
It is noticeable that there are explicit costs associated with the considerable increase in environmental regulatory censoring. One good example of this is that capital market investors have recognised the potential environmental risk and priced it into their investment decisions. The immediate consequence is an inflated cost of capital faced by polluting firms. From an equity market's perspective, Bolton and Kacperczyk [22] document that the stocks of firms with high carbon emissions are associated with higher stock returns for both the US and international stocks, consistent with a higher level of cost of equity capital for eco-harmful companies. According to Engle et al. [23] stock investors can hedge against climate risk by forming dynamic portfolios that are long on the winners of climate change and short the losers. Moreover, climate risk is proxied by a list of topics that, as covered by newspapers, relate to discussions about climate risk including extreme weather events (e.g., floods, hurricanes, droughts, wildfires and extreme temperatures), physical changes to the planet (e.g., sea-level changes, glacial melting and ocean temperatures), regulatory discussions, technical progress in alternative fuel delivery and the price of fossil fuels.

For instance, Krueger et al. [24] conduct a survey study of institutional investors' views toward climate risk with the average respondent institutional investor believing that climate risk has financial implications for their portfolio management. Additionally, Choi et al. [25] offer more direct evidence on investor attention to global warming by showing that the Google search volume index, an indicator of retail investor attention, increases with abnormal local temperature jumps while stocks of carbon-intensive firms underperform firms with low carbon emissions in abnormally warm weather. Dimson et al. [26,27] use proprietary data to analyse institutional investors' engagement in corporate ESG issues and empirically demonstrate the value-enhancing effects of shareholder engagement.

Corroborating evidence exists in the debt market too. Chava [28] uses firms' environmental ratings taken from the MSCI KLD database to show a higher interest rate on loans issued to firms with significant environmental externalities (concerns), while Jung et al. [29] examine a limited sample of firms that voluntarily disclose carbon emissions covered in the Carbon Disclosure Project survey and document a positive association between the cost of debt and the firm's willingness to disclose carbon emissions. While there is no direct evidence on corporate greenness and debt contracting, Hasan et al. [30] study the impact of corporate social capital and find that high social capital firms face loosened nonprice loan terms and lower bank loan and bond spreads.

Corporate environmental commitments are also crucial means to build up firms' social capital. Ex-ante corporate environmental engagement demonstrates a firm's readiness in handling environmental crises and enables it to manage a harmonious relationship with local communities [31-35]. Ample evidence highlights the long-term view of socially responsible firms. For example, socially responsible companies are less likely to engage in profitable insider trading [36], earnings management [37,38], corporate fraud [39] and corruption [40].

A non-opportunistic social reputation is important for companies in the long run. When corporate environmental misconduct is on the horizon, high social capital companies or eco-friendly companies can mobilise community support, easing tension between firms and regulators, and reducing compliance costs. In keeping with this view, Flammer [41] documents a cushioned stock market reaction to negative corporate environmental news for firms with high ex-ante environmental performance. In her subsequent work, Flammer [42] finds that firms that commit to sustainable practices are more likely to win government procurement contracts, indicating that firms, through their stakeholder engagements, earn government trust, ultimately increasing profitability.

\subsection{Greening the Economy by Greening the Financial System-The Example of the Impact of Green Bonds}

The financial system plays a vital role in guiding and allocating capital efficiently in the real economy. Thus, greening the financial system is a first and essential step in greening the economy itself. The idea of greening the financial system globally originated from the G20 Summit in 2016 and, in line with Batrancea et al. [43] findings relating to the 
fact that the financial system needs to be supported by government fiscal and monetary policy designed to promote the greening of the finance system, the following year the network of central banks and supervisors for greening the financial system-Network for Greening the Financial System (NGFS) - was launched at the Paris One Planet Summit on 12 December 2017. As of 20 May 2020, there were 66 members and 12 observers in the NGFS which contribute to the development of environmental and climate risk management in the sector and facilitate the transition toward a more sustainable economy.

In particular, the most immediate action identified as needed to affect the greening of the financial system is to advocate green financing instruments and activities, such as green bonds, green loans, green equity, green derivatives, and so on. Due to their novelty and the lack of data relating to green loans, green equity and green derivatives, most of the literature focuses on green bonds. In this section, we will analyse the literature discussing the real impact of green bond issuances on the bond and equity markets.

The literature documents the mixed influence of green labels on corporate bond spreads. This mixed evidence could be explained by two competing motives for issuing green bonds. Firstly, via financial motives with the expectation of better financial performance [44] or lower risk [13]. In support of financial motives, Wang et al. [16] document a significant pricing premium of corporate green bonds relative to matched conventional bonds in the context of the Chinese market. They also find that the economic magnitude of this premium is more pronounced for issuers with better performance in CSR. As abundant literature shows [12,28,35], better CSR performance is associated with better financial performance and lower risk reinforcing Wang et al. [16] findings highlighting the role of pecuniary motives for green bond issuances. Moreover, Flammer [42] documents that the use of green bonds improves a firm's long-term value and operating performance, green innovations, and the ownership of long-term and green investors, which further supports financial motives.

The second motive is non-pecuniary-including the social preferences and social signalling motivating investors to hold green assets regardless of their financial motives (for instance, see [45,46]). The effect of non-pecuniary motives is consistent with Zerbib's [47] finding that there is a small negative premium between green bonds and counterfactual conventional bonds. However, the economic magnitude of this negative premium is only -2 basis points in their sample. Similarly, Tang and Zhang [48] find no significant premium for green bonds.

On the equity market, empirical studies document a consistent positive impact on stock returns associated with green bonds. For instance, Tang and Zhang [48] show that positive stock returns around green bond announcements are associated with an increase of institutional ownership and stock liquidity. Wang et al., [16,17] find positive abnormal stock returns after the issuance of green bonds consistent with stakeholder value maximisation theory. A similar positive announcement return is also documented by Flammer [42]. This empirical evidence emphasises the role of green bonds in enhancing equity performance and value creation.

\section{Green Finance Development, Typologies and Measurements}

So far, there is no standardised definition or framework for identifying green assets globally. For instance, the European Union and China have distinct definitions for green finance. Although the majority of descriptions of green financial products in both catalogues overlap, there are some controversial elements. For example, clean coal is treated as a green product and is supported by green bonds in China, while not in Europe. One of the reasons is that developed and developing nations have different priorities when setting green finance standards and, likely more immediate financial concerns drive policy in the shorter term. However, the Chinese government's priorities are not only centred on the reduction of carbon emissions but also consider a range of environmental issues, including air, water and soil pollution. While in Europe, some of these issues are currently not as serious a problem. 
Thus, the definitional issues are foundational considerations in the fight to achieve a better balance between economic and green outcomes in business. Without appropriate and universal definitions, the work of scholars in the field of evaluating green finance outcomes for instance-and a critical area too-are devoid of fundamental efficacy as the results reported including those of falling pollution by Zhou et al. [49,50] are mitigated given the underlying definitional circumstances are unknown. We, therefore, consider some fundamental questions in order to consider the foundations of this area of research.

Technically, the financial instruments that invest in greening activities could be considered as green financial instruments, such as green equity, green bonds, green derivatives and so on. Due to the complexity of equity and financial derivatives, the most influential and popular green financial instruments are bank loans and corporate bonds. We review the definitions and measures for green bonds and green loans below.

\subsection{The Development of Green Bonds}

Green bonds are a nascent fixed income asset class that are issued by governments, corporations and other institutions used to finance environmental and climate-friendly projects, such as renewable energy, recycling and green infrastructure. The definition of 'green' across institutions is very different. For example, the green bond definitions are different in Bloomberg, Climate Bonds Initiative (CBI) and Thomas Reuters. Wang et al. [16,17] compose a comprehensive dataset to depict growing trends within the green bond market using green bonds data from multiple sources. According to Wang et al. [16,17] and as described above, the green bond market took off in 2013 but has experienced significant growth since then. Further, Wang et al. $[16,17]$ break down the green bond amounts issued in 2018 by country and show that China, Sweden, France and Japan accounted for the largest proportions of green bond issuances.

\subsection{The Development of Green Loans and Disclosure}

Similar to green bonds, green loans are bank lending/investments designed to support the transition to a net-zero carbon economy through environmentally responsible projects and climate change mitigation. The initiation of green lending started as early as 2005. Several major U.S. banks, such as Wells Fargo and the Bank of America, started to dedicate resources towards sustainable entrepreneurship at that time. Since then, the instrument's use has grown exponentially Zhou et al. [49]. As most of the regulators do not mandate banks to disclose green lending, it is hard to get an accurate number of how big the green loan market is. However, the Chinese government issued a green credit policy that mandated state-owned and commercial banks disclose their green credit policy starting from 2007.

\subsubsection{International Finance-Measuring the Green Loan Market}

Globally, the International Finance Corporation (IFC) at the World Bank Group proposes a bottom-up approach to estimate and track the size of green loan markets. This approach identifies green loans according to the business nature of a project, corporation and industry. Specifically, the share of green finance can be first identified by examining the actual "use of proceed" at the project level. If the "use of proceed" information is not available or useful, the percentage of green finance that yields environmental benefits could be estimated at the industry level. The implicit assumption is that the firms within the same industry conduct similar environment-friendly activities on average. Besides these, the share of green revenues per operating company could also be used to identify green activities.

The IFC applies this method by combining multiple databases on syndicated bank loans and firm activities to estimate green activities. Of the syndicated loans that closed in 2014, the IFC documents that 3610 out of 4412 financed projects incorporated some green activities. In terms of dollar values, about USD 165 billion dollars were identified as green loans. According to the IFC's definition, 41 percent of green loans belong to real 
estate, while clean energy only accounts for 15 per cent. Across countries, the IFC finds that the total amount of green loans in the United States is the largest, followed by, the United Kingdom, Australia, France, Japan and China. This is not surprising considering the relative size of the financial markets. While, for the percentage of green credit in loan markets, Turkey has the largest share with more than 70 percent.

\subsubsection{European Union Taxonomy}

Besides international organizations, the European Union has also made a significant contribution to prompt the sustainable growth of the global economy. The EU has formed a technical expert group (TEG) consisting of experts from almost all elements of the investment chain, including industry sector representatives, academia, environmental experts, civil society and public bodies. To facilitate green investing, the TEG developed a taxonomy to identify the economic activities that make a substantial contribution to climate change mitigation, climate change adaptation, the protection and sustainability of water and marine resources, transition to a circular economy, pollution prevention and control, protection and restoration of biodiversity in ecosystems. This taxonomy was published on 22 June 2020 and entered into force on 12 July 2020.

The EU taxonomy categorizes economic activities into transitional and enabling activities. The transitional activities are economic activities that make a substantial contribution to climate change mitigation based on their own performance, while enabling activities are economic activities that enable a substantial contribution to be made in other activities. For example, using solar panels to generate electricity is an example of a transitional activity, while producing the solar panel itself is an example of an enabling activity.

We consider both transitional and enabling activities as green economic activities. Similar to the IFC's approach, we identify green loans as a loan whose borrower has revenues generated from green economic activities according to EU taxonomy. In order to demonstrate the change in green loan value year-on-year, we have extracted syndicated loan data from Loanconnector and manually matched it to green economic activity as defined by the EU taxonomy. Figures 1 and 2 show the aggregated amount of, and the percentage of, green loans in accordance with the EU taxonomy by year and by country, respectively. We find that green loans account for about $55 \%$ of total loans on average. We also observe that the percentage of green loans increased to about $70 \%$ during the sub-prime crisis of 2008. Geographically, the percentage of green loans are the highest in Spain, Italy and Mexico in contrast to other countries. While Turkey, Chile and South Africa have the lowest percentages of green loans.

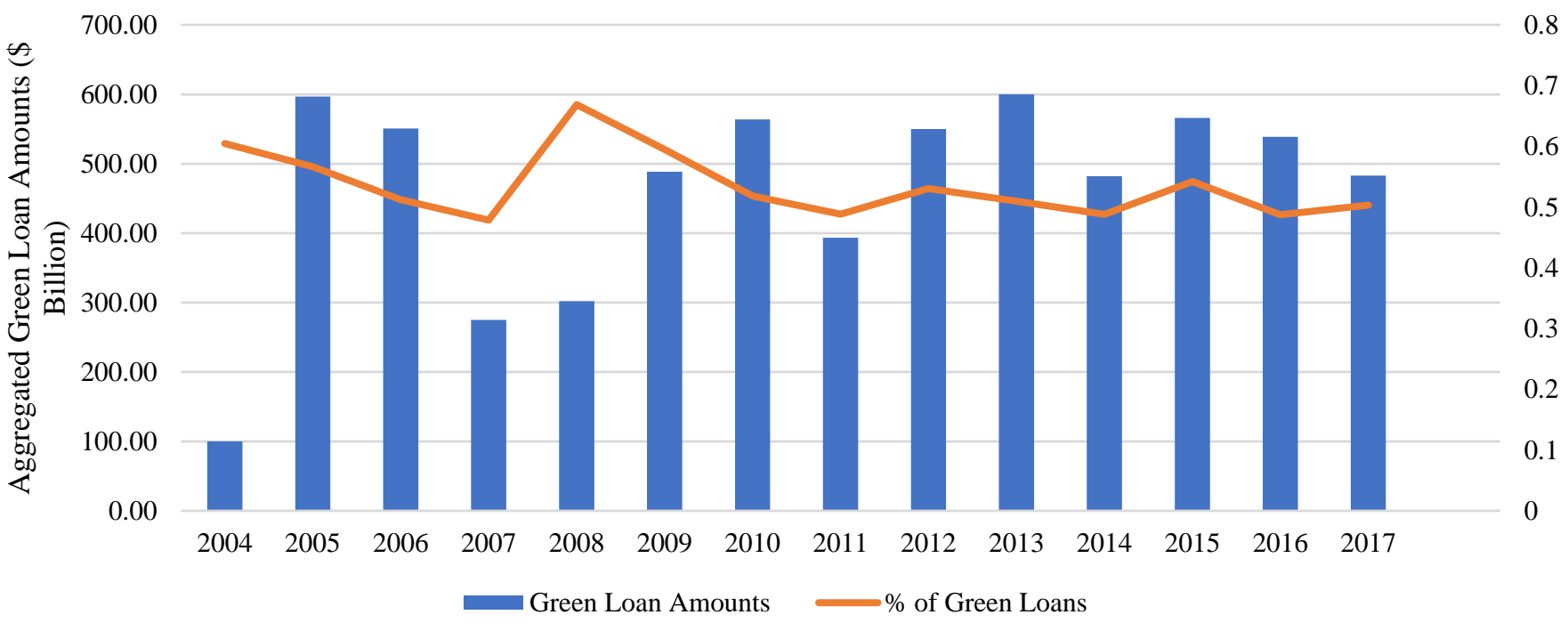

Figure 1. The year distribution of green loans. 


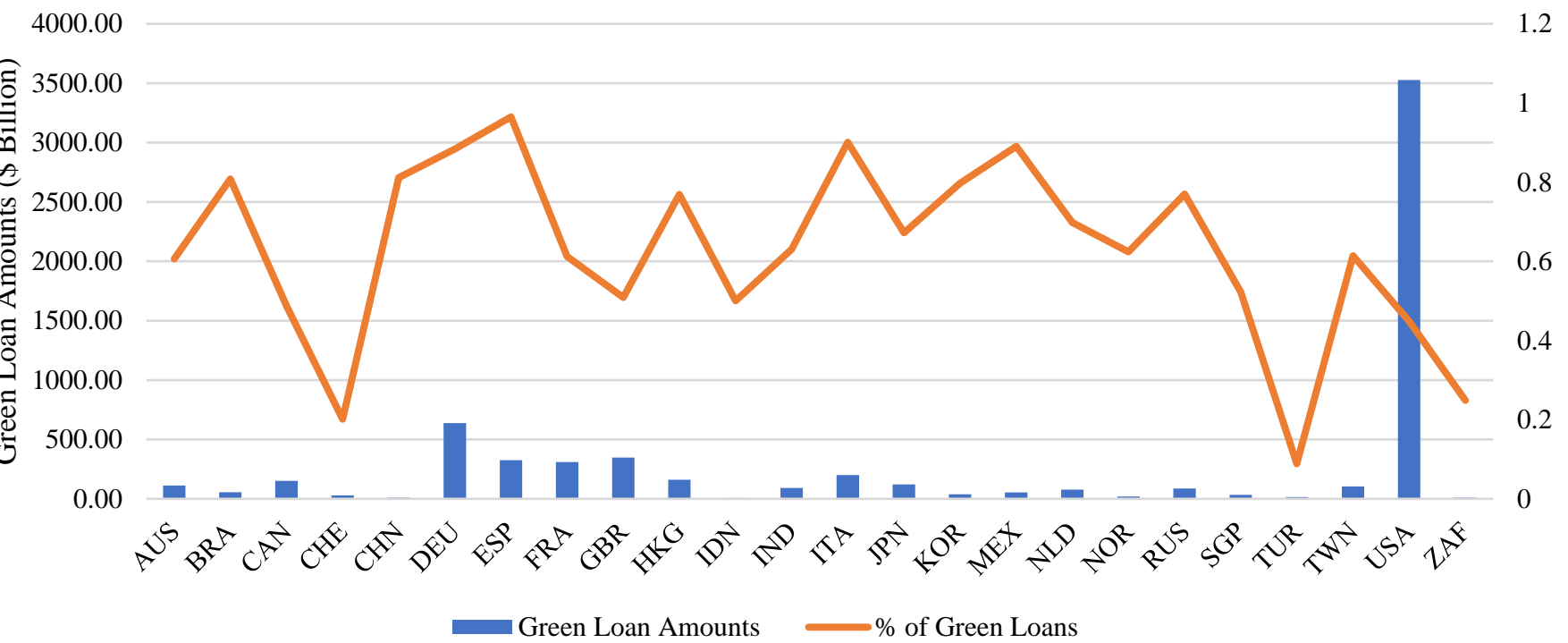

Figure 2. The country distribution of green loans

\section{Concluding Remarks and Future Research}

In this section, we bring the discussion back to our central purpose and consider the challenges and research opportunities inherent in this area. Overall, the research undertaken to date has highlighted difficulties in the analysis of green finance including the lack of consistency in assessing corporate greenness, the ambiguous definition of corporate greenness, and the unavailability of data. However, the research has also identified that: (1) there are positive outcomes being achieved through the application of pressure on companies to respond positively to stakeholders who display a desire to invest in green activities; and (2) that these positive outcomes reinforce the need for, and likely value of, continuing to investigate this critical area of finance activity.

The assessments of financial performance themselves are straightforward as these data appear in well audited financial reports for publicly listed companies. However, social factors remain an elusive concept. A Wall Street Journal article gives a lucid illustration on grading companies based on nonfinancial factors. Tesla, the electric carmaker, was ranked the top ESG performer in the MSCI KLD rating system in 2018, but at the same time was ranked the worst in the FTSE simply because FTSE's rating system evaluates the carbon emissions of a firm's factories rather than its products. To confuse things further, most scoring systems aggregate environmental, social and governance aspects into one single ESG score, which clouds the interacting and countervailing effects among the three fundamentally different pillars of corporate social responsibility. For example, corporate governance, by definition, is intended to protect the returns of shareholders' investments whereas environmental and social commitments of the firm also improve the wellbeing of nonfinancial stakeholders such as customers and suppliers. Often the interests of shareholders are in conflict with those of other stakeholders. By simply combining environmental, social and governance performance, it is difficult to evaluate the true social performance of a firm. Another example is that a polluting firm could excel in its social commitments and corporate governance structure, resulting in a high overall ESG score. In view of the large number of ESG rating companies globally, the evaluation of a company's environmental performance is likely be biased toward the scoring algorithm the companies are being assessed with.

Our literature review finds that another significant challenge faced by most corporate environmental studies is the endogeneity problem. That is, social commitments, such as curtailing carbon emissions, investing in renewable energy, and cleansing production waste engender considerable costs for firms. Such costs could be so prohibitive that only companies performing well can afford to undertake a genuinely eco-friendly transformation. Prior studies attempt to use event-driven econometric approaches to mitigate this 
concern [13]. However, the downside of short-term events is that they do not inform us of the long-term impact of corporate environmental behaviour, nor do we know the average effect of corporate environmental behaviour to a large cross-section of companies including non-event companies.

Defining 'green' is also a challenge since, in practice, different jurisdictions face different environmental problems. For example, the most severe environmental problem in China is air pollution, which is currently not considered a major concern in Europe. Further, driven by the prioritisation of environmental and economic issues, and, as stated above, clean coal is treated as a green project in China but not in Europe. As such, the stage of economic development and cultural predispositions appear to form additional drivers for the divergence of green definitions across countries. In the face of the aforementioned difficulties, we have to admit that it is a big challenge to reconcile the various definitions globally. It is also an urgent task because well-accepted green definitions provide the infrastructure necessary to communicate and coordinate the actions for greening economy as well as to assess outcomes, conduct analysis and compare results.

Aside from the above challenges, which represent opportunities for further research, this literature survey also reveals several research voids related to the existing work. First, a vast majority of corporate environmental performance research has been conducted using a single-country setting, particularly in the US [21,22]. However, it is recognised that country characteristics matter considerably when it comes to corporate environmental behaviour $[51,52]$. Second, while some studies investigate the economic consequences of corporate environmental disclosures $[1,20]$, the examination of the actual contents of environmental disclosures is lacking. This line of research is pivotal because there is no single accepted guideline for companies to disclose their environmental performance. Research on these environmental disclosures, aided by advanced textual analytical techniques, informs regulators of the material environmental information that matters to its shareholders as well as other nonfinancial stakeholders. Finally, an encompassing evaluation of various rating systems is in high demand for future researchers to unify the rating differences and set the focus onto issues that are socially and financially material for investors. Indeed, this is an area on which our future research is focused.

There are limitations to this study that must also be recognized. Firstly, we have focused on two types of green financing only (bonds and loans) without considering the prospects for alternative instruments to be deployed with, perhaps, more effective outcomes. Additionally, this tight focus has meant that we have also considered the literature in the context of the incentivisation of the firms involved rather than from a policy perspective or a system-wide perspective. Thus, we have considered literature that posits findings associated with individual firms and their managers rather than considering wider issues including isomorphic pressure in industries and, other than noting its importance, policy prescriptions that may be used to counter the proclivities of the managers of firms. It is certain that contributors such as Dorry and Schulz [5] and Wang and Zhi [3] are right in their conclusion that green-focused policy frameworks are likely to be essential in moderating the behaviour of firms toward preferring ecologically friendly investment strategies regardless of the economically rational circumstances presented.

Overall, the need for further and more refined research associated with this area is significant. Our ongoing expectation that developed economies will prioritise marketbased solutions in meeting the global ecological sustainability crisis means that we have to understand the strengths and weaknesses of that system intimately in the context of firm activities - what are those things that will truly motivate firms to implement ecologically friendly investment rather than succumb to the temptation to address the environment rhetorically but not practice what is being preached. The rise of green finance markets will bring new financial data needing to be analysed. This study reviews and lays out the literature foundation in a hope to advance our persistent search for means to protect our natural environment for the survival of humanity. 
Author Contributions: Conceptualization, D.G., J.Y. and R.Z.; methodology, D.G., J.Y. and R.Z.; investigation, D.G., J.Y. and R.Z.; writing-original draft preparation, D.G., J.Y. and R.Z.; writingreview and editing, D.G., J.Y. and R.Z.; funding acquisition, J.Y. and R.Z. All authors have read and agreed to the published version of the manuscript.

Funding: This research was funded by Research Collaboration Award at The University of Western Australia, INSPIRE of Climateworks Foundation and National Social Science Foundation of China (Key Program No.18AZD013).

Institutional Review Board Statement: Not applicable.

Informed Consent Statement: Not applicable.

Data Availability Statement: Not applicable.

Conflicts of Interest: The authors declare no conflict of interest.

\section{References}

1. Bolton, P.; Kacperczyk, M.T. Carbon Premium around the World. CEPR Discussion Paper No. DP14567. 2020. Available online: https:/ / ssrn.com/abstract=3594188 (accessed on 20 October 2020).

2. Trippel, E. How green is green enough? The changing landscape of financing a sustainable European economy. ERA Forum 2020, 21, 155-170. [CrossRef]

3. Wang, Y.; Zhi, Q. The Role of Green Finance in Environmental Protection: Two Aspects of Market Mechanism and Policies. Energy Procedia 2016, 104, 311-316. [CrossRef]

4. Batrancea, I.; Rathnaswamy, M.M.; Batrancea, L.; Fatacean, G.; Tulai, H.; Bircea, I.; Rus, M.-I. A Panel Data Analysis on Sustainabiltiy Economic Growth in India, Brazil and Romania. Risk Financ. Manag. 2020, 13, 19.

5. Dörry, S.; Schulz, C. Green financing, interrupted. Potential directions for sustainable finance in Luxembourg. Local Environ. 2018, 23, 717-733. [CrossRef]

6. Friedman, M. The social responsibility of business is to increase its profits. New York Times, 13 September 1970.

7. Jensen, M.C. Value Maximization, Stakeholder Theory, and the Corporate Objective Function. Bus. Ethics Q. 2002, 12, 235-256. [CrossRef]

8. Jensen, M.C.; Meckling, W.H. Theory of the Firm: Managerial Behavior, Agency Costs and Ownership Structure. J. Financ. Econ. 1976, 3, 360. [CrossRef]

9. Tirole, J.; Bénabou, R. Individual and Corporate Social Responsibility. SSRN Electron. J. 2010, 77, 1-19. [CrossRef]

10. Masulis, R.W.; Reza, S.W. Agency Problems of Corporate Philanthropy. Rev. Financ. Stud. 2015, 28, 592-636. [CrossRef]

11. Cheng, I.-H.; Hong, H.G.; Shue, K. Do Managers Do Good with Other Peoples' Money? NBER Working Paper No. 19432.2016. Available online: https:/ / papers.ssrn.com/sol3/papers.cfm?abstract_id=1962120 (accessed on 15 September 2020).

12. Fernando, C.S.; Sharfman, M.P.; Uysal, V.B. Corporate Environmental Policy and Shareholder Value: Following the Smart Money. J. Financ. Quant. Anal. 2017, 52, 2023-2051. [CrossRef]

13. Krueger, P. Corporate Goodness and Shareholder Wealth. J. Financ. Econ. 2015, 115, 304-329. [CrossRef]

14. Chang, M.; Ma, L.; Yu, J. The Value Relevance of Corporate Social Responsibility Around the World. Working Paper; The University of Western Australia: Crawley, WA, Australia, 2020.

15. Karpoff, J.M.; Lott, J.R., Jr.; Wehrly, E.W. The Reputational Penalties for Environmental Violations: Empirical Evidence. J. Law Econ. 2005, 48, 653-675. [CrossRef]

16. Wang, J.; Chen, X.; Li, X.; Yu, J.; Zhong, R. The market reaction to green bond issuance: Evidence from China. Pac. Basin Financ. J. 2020, 60, 101294. [CrossRef]

17. Wang, L.; Hossain, M.M.; Yu, J. Environmental Events and Firm Performance: Chinese Evidence. Unpublished working paper. 2020.

18. Cao, J.; Titman, S.; Zhan, X.; Zhang, W.E. ESG Preference, Institutional Trading, and Stock Return Patterns. Working Paper. 2020. Available online: https:/ / ssrn.com/abstract=33536 (accessed on 20 October 2020).

19. Cui, B.; Docherty, P. Stock Price Overreaction to ESG Controversies. Working Paper. 2020. Available online: https://ssrn.com/ abstract $=35599$ (accessed on 15 September 2020).

20. Heflin, F.; Wallace, D. The BP Oil Spill: Shareholder Wealth Effects and Environmental Disclosures. J. Bus. Financ. Account. 2017, 44, 337-374. [CrossRef]

21. Shapiro, J.S.; Walker, R. Why Is Pollution from US Manufacturing Declining? The Roles of Environmental Regulation, Productivity, and Trade. Am. Econ. Rev. 2018, 108, 3814-3854. [CrossRef]

22. Bolton, P.; Kacperczyk, M.T. Do Investors Care about Carbon Risk? NBER Working Paper No. 26968. 2020. Available online: https:/ / www.nber.org/papers/w26968 (accessed on 20 October 2020).

23. Engle, R.F.; Giglio, S.; Kelly, B.; Lee, H.; Stroebel, J. Hedging Climate Change News. Rev. Financ. Stud. 2020, $33,1184-1216$. [CrossRef]

24. Krueger, P.; Sautner, Z.; Starks, L.T. The Importance of Climate Risks for Institutional Investors. Rev. Financ. Stud. 2020, 33, 1067-1111. [CrossRef] 
25. Choi, D.; Gao, Z.; Jiang, W. Attention to Global Warming. Rev. Financ. Stud. 2020, 33, 1112-1145. [CrossRef]

26. Dimson, E.; Karakaş, O.; Li, X. Active Ownership. Rev. Financ. Stud. 2015, 28, 3225-3268. [CrossRef]

27. Dimson, E.; Karakaş, O.; Li, X. Coordinated Engagements. Working Paper. 2019. Available online: https://ssrn.com/abstract=32 090 (accessed on 9 October 2020).

28. Chava, S. Environmental Externalities and Cost of Capital. Manag. Sci. 2014, 60, 2223-2247. [CrossRef]

29. Jung, J.; Herbohn, K.; Clarkson, P. Carbon Risk, Carbon Risk Awareness and the Cost of Debt Financing. J. Bus. Ethics 2018, 150, 1151-1171. [CrossRef]

30. Hasan, I.; Hoi, C.K.S.; Wu, Q.; Zhang, H. Does Social Capital Matter in Corporate Decisions? Evidence from Corporate Tax Avoidance. J. Account. Res. 2017, 55, 629-668. [CrossRef]

31. Porter, M.E.; Kramer, M.R. Creating shared value (CSV). J. Direct Data Digit. Mark. Pract. 2011, 12, 380.

32. Porter, M.E. Towards a dynamic theory of strategy. Strat. Manag. J. 1991, 12, 95-117. [CrossRef]

33. Porter, M.E.; Kramer, M.R. Strategy and society: The link between competitive advantage and corporate social responsibility. Harv. Bus. Rev. 2006, 84, 78-92. [PubMed]

34. Russo, M.V.; Fouts, P.A. A Resource-Based Perspective on Corporate Environmental Performance and Profitability. Acad. Manag. J. 1997, 40, 534-559.

35. El Ghoul, S.; Guedhami, O.; Kwok, C.C.Y.; Mishra, D.R. Does corporate social responsibility affect the cost of capital? J. Bank. Financ. 2011, 35, 2388-2406. [CrossRef]

36. Gao, F.; Lisic, L.L.; Zhang, I.X. Commitment to social good and insider trading. J. Account. Econ. 2014, 57, 149-175. [CrossRef]

37. Chih, H.-H.; Shen, C.-H.; Kang, F.-C. Corporate Social Responsibility, Investor Protection, and Earnings Management: Some International Evidence. J. Bus. Ethics 2007, 79, 179-198. [CrossRef]

38. Hong, Y.; Andersen, M.L. The Relationship between Corporate Social Responsibility and Earnings Management: An Exploratory Study. J. Bus. Ethics 2011, 104, 461-471. [CrossRef]

39. Harjoto, M.A. Corporate social responsibility and corporate fraud. Soc. Responsib. J. 2017, 13, 762-779. [CrossRef]

40. Luo, Y. The changing Chinese culture and business behavior: The perspective of intertwinement between guanxi and corruption. Int. Bus. Rev. 2008, 17, 188-193. [CrossRef]

41. Flammer, C. Corporate Social Responsibility and Shareholder Reaction: The Environmental Awareness of Investors. Acad. Manag. J. 2013, 56, 758-781. [CrossRef]

42. Flammer, C. Competing for government procurement contracts: The role of corporate social responsibility. Strat. Manag. J. 2018, 39, 1299-1324. [CrossRef]

43. Batrancea, I.; Batrancea, L.; Rathnaswamy, M.M.; Tulai, H.; Fatacean, G.; Rus, M.-I. Greening the Financial System in USA, Canada and Brazil: A Panel Data Analysis. Mathematics 2020, 8, 13. [CrossRef]

44. Hartzmark, S.M.; Sussman, A.B. Do Investors Value Sustainability? A Natural Experiment Examining Ranking and Fund Flows. J. Financ. 2019, 74, 2789-2837. [CrossRef]

45. Riedl, A.; Smeets, P. Why Do Investors Hold Socially Responsible Mutual Funds? J. Financ. 2017, 72, 2505-2550. [CrossRef]

46. Hong, H.; Kacperczyk, M. The price of sin: The effects of social norms on markets. J. Financ. Econ. 2009, 93, 15-36. [CrossRef]

47. Zerbib, O.D. The effect of pro-environmental preferences on bond prices: Evidence from green bonds. J. Bank. Financ. 2019, 98, 39-60. [CrossRef]

48. Tang, D.Y.; Zhang, Y. Do Shareholders Benefit from Green Bonds? J. Corp. Financ. 2020, 61, 101427. [CrossRef]

49. Zhou, X.; Tang, X.; Zhang, R. Impact of green finance on economic development and environmental quality: A study based on provincial panel data from China. Environ. Sci. Pollut. Res. 2020, 27, 19915-19932. [CrossRef]

50. Zhou, X.Y.; Caldecott, B.; Hoepner, A.; Wang, Y. Bank Green Lending and Credit Risk: An Empricial Analysis of China's Green Credit Policy; Working Paper; Smith School of Enterprise and the Envronment, University of Oxford: Oxford, UK, 2020.

51. Cai, Y.; Pan, C.H.; Statman, M. Why do countries matter so much in corporate social performance? J. Corp. Financ. 2016, 41, 591-609. [CrossRef]

52. Ioannou, I.; Serafeim, G. What drives corporate social performance? The role of nation-level institutions. J. Int. Bus. Stud. 2012, 43, 834-864. [CrossRef] 